\title{
PENGETAHUAN PENCEGAHAN KAKI DIABETIK PENDERITA DIABETES MELITUS BERPENGARUH TERHADAP PERAWATAN KAKI
}

\author{
Srimiyati ${ }^{1}$ \\ ${ }^{1}$ Program Studi Ilmu Keperawatan, Fakultas IImu Kesehatan Universitas Katolik Musi Charitas, Sumatera Selatan \\ Email : srimiyati@ukmc.ac.id
}

\begin{abstract}
ABSTRAK
Latar Belakang: Komplikasi yang sering terjadi pada penderita diabetes melitus salah satunya kaki diabetik. Masalah kaki diabetik memerlukan waktu dan biaya cukup banyak. Pencegahan kaki diabetik dapat dilakukan dengan perawatan kaki. Penderita diabetes yang memiliki pengetahuan cukup tentang perawatan kaki diabetik menjadi dasar dan memotivasi untuk mengendalikan komplikasi penyakitnya.
\end{abstract}

Tujuan: Penelitian ini bertujuan untuk mengetahui hubungan pengetahuan dan pencegahan kaki diabetik bagi penderita diabetes

Metode: Penelitian ini adalah descriptive correlational, menggunakan pendekatan cross sectional study. Populasinya seluruh penderita diabetes melitus yang berobat jalan. Sampel berjumlah 53 responden, pengambilan sampel menggunakan purposive sampling. Pengumpul data menggunakan kuesioner terdiri dari 20 item untuk menggali pengetahuan pencegahan kaki diabetik dan 15 item perawatan kaki. Penelitian dilakukan di RSI Siti Khatijah Palembang

Hasil: penelitian menunjukkan sebagian besar responden perempuan $(58,5 \%)$, usia $\geq 55$ tahun $(83,0 \%)$, pendidikan menengah kebawah $(67,9 \%)$, menderita diabetes mellitus $\geq 5$ tahun $(58,5 \%)$, responden yang memiliki pengetahuan pencegahan kaki diabetik dengan kriteria tinggi sebanyak $36(67,9 \%)$, melakukan perawatan kaki diabetik $(60,4 \%)$. Hasil uji statistik chi squere menunjukkan ada hubungan yang signifikan antara pengetahuan dan perawatan kaki $(p=0,024$; $\mathrm{OR}=4.767)$.

Kesimpulan: Ada hubungan yang signifikan antara pengetahuan dan perawatan kaki pada pasien diabetes. Pasien diabetes yang memiliki pengetahuan baik mengenai perwatan kaki berpeluang 4.767 kali lebih besar dalam melakukan perawatan kaki dari pada yang memiliki pengetahuan kurang.

Kata Kunci: Diabetes Melitus; Kaki Diabetik; Pengetahuan; Perawatan Kaki

\section{PENDAHULUAN}

Diabetes Melitus merupakan penyakit kronis yang terjadi ketika pankreas tidak menghasilkan insulin yang cukup atau ketika tubuh tidak dapat secara efektif menggunakan insulin yang dihasilkan (WHO, 2015). Tahun 2015 Internasional Diabetes Federation, mencatat sebanyak 415 juta orang menderita diabetes melitus. Jumlah ini diperkirakan akan meningkat menjadi 642 juta orang pada tahun 2040.

Meningkatnya prevalensi penderita diabetes melitus tentu saja akan menambah angka kejadian komplikasi baik pada tingkatan sel maupun anatomic. Penderita diabetik sangat berisiko terhadap kejadian luka kaki, pada umumnya kronis dan sulit penyembuhanya. Menurut Gordois at al (2003) dalam Maryunani (2013) sekitar 15\% pasien diabetes akan mengalami setidaknya satu ulkus tungkai selama hidup mereka dan sering berujung pada amputasi jari kaki, kaki atau tungkai. Penderita diabetik di Indonesia menempati urutan ke tujuh setelah China, India, Amerika, Brazil, Rusia dan Mexico.

Populasi penderita diabetes di Indonesia tahun 2015 sebesar 10 juta orang (Cavan at al, 2015). Penyulit kaki diabetes menjadi masalah rumit karena belum banyak peminat yang termotivasi menekuni 
perawatan kaki diabetes. Di samping itu masih terbatasnya pendidikan yang khusus untuk mengelola kaki diabetes. Pengetahuan mengenai kaki diabetes masyarakat khususnya diabetesi dirasakan masih rendah dan besarnya biaya pengelolaan kaki diabetes (Ernawati, 2013).

Kematian akibat ulkus gangren pada penyandang diabetes di Indonesia mencapai $32 \%$ sedangkan jumlah amputasi sebesar 30\% (Maryunani, 2013). Salah satu tindakan pencegahan terjadinya kaki diabetik pada penyandang diabetes dengan perawatan kaki. Menurut Ardi, Damayanti, Sudirman (2013) dalam penelitiannya, terdapat hubungan antara kepatuhan perawatan kaki dan risiko ulkus kaki. Penderita diabetes perlu mengetahui perawatan kaki diabetik dengan baik guna mencegah ulkus gangren bahkan amputasi. Pengetahuan diperlukan untuk membentuk sikap dan tindakan seseorang (Notoatmodjo, 2012b).

Berdasarkan wawancara tidak tidak terstruktur yang dilakukan peneliti kepada 4 dari 6 penderita diabetes yang berobat di Poli RSI Siti Khadijah mengatakan belum mengetahui cara pencegahan kaki diabetik. Pengetahuan meraka sebatas kaki jangan sampai terluka, menghindari sepatu atau sandal yang sempit karena dapat menyebabkan luka pada kaki. Sementara 2 penderita yang lain mengatakan pernah mengikuti seminar cara mencegah komplikasi diabetes dan perawatan kaki penderita diabetes.

\section{METODE}

Penelitian ini merupakan penelitian descriptive correlational Arifin, (2011) yang bertujuan untuk mengetahui hubungan variabel independen (pengetahuan perawatan Kaki) dengan variabel dependen (perawatan kaki), dengan menggunakan pendekatan cross sectional study (Nursalam, 2013).

Penelitian dilakukan di Poli Klinik Penyakit Dalam Rumah Sakit Islam Siti Khadijah Palembang berdasarkan surat no: 205/DIR/1.5/IV/2016. Sampel pada penelitian ini adalah penderita diabetes melites yang datang berobat di Poli, sebanyak 53 responden. Pengambilan sampel dengan cara purposive sampling (Nursalam, 2013).

Instumen pengumpul data pada penelitian ini menggunakan 3 jenis kuesioner yaitu, kuesioner A karakteristik responden dibuat sendiri oleh peneliti terdiri dari (jenis kelamin, usia, pendidikan, pekerjaan dan lama menderita diabetes). Kuesioner B (pengetahuan pencegahan kaki diabetik), kuesioner ini diadopsi dari kuesioner yang dikembangkan oleh Kowalak (2012) dan Maryunani (2013). Peneliti melakukan uji validitas dan reliabilitas kepada 20 responden. Kuesioner dinyatakan valid setelah 2 kali revisi dengan nilai $r$ hasil pada rentang 0.468-0.650 dan Alpha Cronbach's 0.769. Sedangkan Kuesioner C (perawatan kaki) berjumlah 15 pertanyaan mengadopsi dari penelitian Diani (2013). Kuesioner dilakukan uji validitas dan reliabilitas kepada 30 responden dengan Alpha Cronbach's 0,852.

Pengumpulan data dialakukan selama 15 hari (24 Mei - 04 Juni 2016) pada saat responden berobat ke Poli. Peneliti mengawali proses penelitian dengan kontrak waktu dengan responden, menjelaskan maksud, tujuan penelitian, menjelaskan hak responden. Setelah sepakat, peneliti memberi 
waktu kepada responden kurang lebih selama 10-15 menit untuk mengisi kuesioner yang sudah disiapkan. Analisis data untuk mengetahui hubungan variabel pengetahuan dengan perawatan kaki menggunakan Uji Chi Square (Riwidikdo, 2013).

\section{HASIL}

Hasil penelitian pada karakteristik responden didapatkan sebanyak 58.5\% perempuan. Responden yang berusia $\geq 55$ tahun sebanyak $83 \%$. Latar belakang pendidikan menengah ke bawah sebanyak 67.9\%. Lama menderita diabet lebih dari 5 tahun Sebanyak 58.5\%. Pengetahuan tentang perawatan kaki diabetik dengan kategori tinggi sebanyak 67.9\%. Responden yang sudah yang melakukan perawatan kaki diabetes sebanyak $60.4 \%$. (Tabel 1 )

Terdapat 11 responden $(64.7 \%)$ berpengetahuan rendah dan tidak melakukan perawatan kaki, namun ada 6 (35.3\%) responden yang berpengetahuan rendah tetap melakukan perawatan kaki. Terdapat 26 (72.2\%) responden yang berpengetahuan tinggi dan melakukan perawatan kaki, namun ada $10 \quad(27.8 \%) \quad$ responden yang berpengetahuan tinggi tapi tidak melakukan perawatan kaki. (Tabel 2)

Hasil uji statistik $p$ value sebesar 0.024 pada alpha $5 \%$ dapata disimpulkan terdapat hubungan antara pengetahuan dan perawatan kaki. Analisis kekuatan antara variabel pengetahuan dan perawatan kaki didapatkan nilai OR sebesar 4.767 (95\% Cl: 1.38-16.36) artinya responden yang memiliki pengetahuan tinggi mempunyai peluang 4.767 kali melakukan perawatan kaki dibandingkan dengan responden yang memiliki pengetahuan rendah. (Tabel 2).

\section{PEMBAHASAN}

\section{Gambaran Karakteristik Responden}

Hasil penelitian ini didapatkan sebagian besar perempuan. Mengacu pada pendapat Lueckenotte cit Sofiana (2011) perempuan lebih banyak terkena diabetes dibanding pria terutama diabetes melites tipe 2. Hal ini disebabkan oleh penurunan produksi hormon estrogen yang menjaga keseimbangan kadar gula darah dan meningkatkan penyimpanan lemak.

Responden penelitian ini berada pada kelompok umur di atas 55 tahun. Diabetes melites sering terjadi setelah usia 40 tahun (Smeltzer et al., 2010). Dengan bertambah usia akan terjadi gangguan tolerensi glukosa. Proses menua juga menimbulkan perubahan fisiologis berpengaruh pada homeostasis. Salah satunya adalah perubahan fungsi sel beta pankreas. Proses degeneratif sel beta akan menimbulkan ketidakadequatan dalam menghasilkan insulin dan berdampak pada peningkatan kadar gula darah. Merujuk pada hasil penelitian Sundari (2009), perubahan karena usia seperti perubahan vaskuler berkaitan dengan terjadinya resistensi insulin perifer pada diabetes tipe 2 . Menurunya intoleransi glukosa berpengaruh pada sensitivitas sel perifer terhadap insulin. Hal inilah yang menyebabkan peningkatan kadar gula darah pada usia lanjut. 
Srimiyati| Pengetahuan Pencegahan Kaki Diabetik Penderita Diabetes Melitus Berpengaruh Terhadap Perawatan Kaki

Tabel 1. Karakteristik Responden di Poli $(n=53)$

\begin{tabular}{lcc}
\hline Karakteristik & Frekuensi & Persentase \\
\hline Jeis Kelamin & & \\
$\quad$ Laki-laki & 22 & $41.5 \%$ \\
$\quad$ Perempuan & 31 & $58.5 \%$ \\
Usia & & \\
$\quad \quad 55$ tahun & 9 & $17.0 \%$ \\
$\quad \geq 55$ tahun & 44 & $83.0 \%$ \\
$\begin{array}{l}\text { Pendidikan } \\
\quad \text { Menengah kebawah }\end{array}$ & & $67.9 \%$ \\
$\quad$ Perguruan tinggi & 36 & $32.1 \%$ \\
Lama Menderita & 17 & \\
$\quad<5$ tahun & & $41.5 \%$ \\
$\quad \geq 5$ tahun & 22 & $58.5 \%$ \\
Pengetahuan & 31 & $32.1 \%$ \\
$\quad$ Rendah & & $67.9 \%$ \\
$\quad$ Tinggi & 17 & $39.6 \%$ \\
Melakukan Perawatan Kaki & 36 & $60.4 \%$ \\
$\quad$ Yidak & &
\end{tabular}

Tabel 2. Hubungan Pengetahuan dengan Perawatan Kaki di Poli $(n=53)$

\begin{tabular}{|c|c|c|c|c|c|c|c|c|}
\hline \multirow{3}{*}{ Pengetahuan } & \multicolumn{4}{|c|}{ Perawatan Kaki } & \multirow{2}{*}{\multicolumn{2}{|c|}{ Total }} & \multirow{3}{*}{$\begin{array}{c}\text { OR } \\
(95 \% \mathrm{Cl})\end{array}$} & \multirow{3}{*}{$p$-value } \\
\hline & \multirow{2}{*}{$\begin{array}{c}\text { Tidak } \\
f\end{array}$} & \multicolumn{3}{|c|}{ Ya } & & & & \\
\hline & & $\%$ & $f$ & $\%$ & $f$ & $\%$ & & \\
\hline Rendah & 11 & 64.7 & 6 & 35.3 & 17 & 100 & 4.767 & \\
\hline Tinggi & 10 & 27.8 & 26 & 72.2 & 36 & 100 & $(1.38-16.36)$ & 0.024 \\
\hline Total & 21 & 39.6 & 32 & 60.4 & 53 & 100 & & \\
\hline
\end{tabular}

Chi Square test

Hasil penelitian ini sebagian besar pendidikan menengah ke bawah. Seseorang yang berpendidikan menengah, memiliki kemampuan menerima, mengolah informasi dengan baik. Latar pendidikan seseorang berpengaruh pada kemampuan memahami obyek dan informasi. Mengacu pada konsep Notoatmodjo (2012b) bahwa semakin tinggi pendidikan semakin mudah menenima, mengolah informasi.

Lama menderita diabetes, responden pada penelitian ini sebagian besar menderita diabetes lebih 5 tahun. Menurut Smeltzer et al (2010) prevalensi neuropati meningkat bersamaan dengan bertambahnya usia dan. lamanya penyakit. Hampir setiap responden mengatakan dirinya mengetahui terkena diabetes berdasarkan hasil pemeriksaan gula darah. Dengan demikian sesungguhnya lamanya menderita diabetes tidak secara jelas menggambarkan kapan awal proses penyakit itu, karena umumnya penderita mencari pertolongan setelah merasakan keluhan ataupun sudah terjadi komplikasi. Padahal proses penyakit sudah terjadi pada waktu sebelumnya.

Berdasarkan temuan pada penelitian ini, pengetahuan pencegahan kaki diabetik sebagian besar memiliki pengetahuan tinggi. Pengetahuan merupakan salah satu unsur yang berdampak pada perilaku. Hasil ini didukung oleh penelitian Rias (2015) bahwa pengetahuan responden tentang ulkus diabetik ada $16(54 \%)$ memiliki pengetahuan 
cukup. Pengetahuan menjadi bagian penting untuk membentuk perilaku. Pengetahuan yang tinggi dapat membantu mengatasi kebingungan, meningkatkan kepercayaan diri dan memotivasi untuk manajemen perawatan dirinya lebih baik.

Berdasarkan hasil penelitian bahwa sebagian besar responden sudah melakukan perawatan kaki. Kondisi ini menggambarkan wujud upaya pencegahan komplikasi kaki diabetik secara dini. Menurut Soegondo (2009) setiap pasien perlu mengetahui perawatan kaki diabetik dengan baik untuk mencegah terjadinya ulkus gangren dan amputasi. Perawatan kaki bagi penderita diabetes sangat penting karena kaki merupakan organ tubuh yang rentan terhadap luka. Di samping itu kaki sebagai penyangga tubuh memiliki banyak syaraf yang terhubung dengan organ tubuh lainnya.

\section{Pengetahuan pencegahan kaki diabetik dengan perawatan kaki.}

Hasil penelitian menunjukkan bahwa responden yang memiliki pengetahuan tinggi sebagian besar melakukan pencegahan dengan perawatan kaki dibanding dengan responden berpengatahuan rendah. Hasil penelitian ini sejalan dengan penelitian Diani (2013) bahwa klien diabetes tipe 2 yang berpengetahuan baik memiliki praktik perawatan kaki lebih baik dibanding dengan klien diabetes tipe 2 yang pengetahuan kurang.

Berdasarkan analisis uji statistik chi-square, ada hubungan yang signifikan antara pengetahuan pencegahan dengan perawatan kaki diabetik. Penderita diabetes melitus yang berpengetahuan tinggi mempunyai peluang 4.76 kali melakukan perawatan kaki dibandingkan dengan yang berpengetahuan rendah.

Mengacu pada teori dalam Notoatmodjo (2012b), pengetahuan merupakan hasil dari tahu, dan ini terjadi setelah orang melakukan pengindraan terhadap suatu objek tertentu. Pengetahuan merupakan domain penting dalam membentuk tindakan seseorang. Menurut pendapat Desalu et al. (2011) pengetahuan yang baik memiliki praktik perawatan kaki yang baik. Selanjutnya Basuki cit Soegondo (2009) menyatakan penyandang diabetes yang mempunyai pengetahuan cukup tentang diabetes, mampu mengubah perilakunya dan mengendalikan kondisi penyakitnya.

Pengetahuan yang dimiliki seseorang dapat berpengaruh terhadap pola pikir dalam melakukan tindakan. Demikian pula ketika seseorang melakukan analisa penyakit atau perubahan yang terjadi dalam dirinya. Pengetahuan juga sangat erat hubungannya dengan cara seseorang memperhatikan perubahan pada dirinya, misalnya ketika kakinya mulai terasa baal atau dingin.

Pengetahuan responden yang tinggi dalam penelitian ini dimungkinkan tidak saja dipengaruhi oleh pendidikan formal melainkan oleh faktor internal, eksternal dan faktor pendukung yang dapat meningkatkan pengetahuan, misalnya belajar secara mandiri (otodidak) melalui berbagai media tentang diabetes melites.

Upaya pencegahan kaki diabetik dilakukan dengan memberi pelembab, memakai sandal atau sepatu yang sesuai, segera mencari petolongan apabila mulai timbul rasa baal pada kaki, dan atau luka 
sekalipun kecil. Perawatan kaki secara rutin juga dapat dilakukan dengan mencuci kaki menggunakan air hangat, mengeringkan kaki sampai pada sela-sela jari kaki, melakukan pemeriksaan setiap hari dan memperhatihan perubahan-perubahan yang terjadi pada kaki.

Mencegah terkena kaki diabetik lebih baik daripada usaha menyembuhkan. Menurut Saskatchewan Ministrry of Health (2008) dalam Sihombing (2012), proses penyembuhan kaki diabetik membutuhkan waktu yang lama.

\section{KESIMPULAN DAN SARAN}

Berdasarkan hasil penelitian disimpulkan bahwa pengetahuan pencegahan kaki diabetes berhubungan secara signifikan terhadap kemampuan pasien dalam merawat kaki. Pasien diabetes yang memiliki pengetahuan baik mengenai perwatan kaki berpeluang 4.767 kali lebih besar dalam melakukan perawatan kaki dari pada yang memiliki pengetahuan kurang. Hendaknya ada pengembangan pendidikan kesehatan tentang pencegahan kaki diabetik dan pendampingan perawatan kaki sebagai upaya preventif dalam meningkatkan life expectancy bagi penderita diabetes.

\section{DAFTAR PUSTAKA}

Ardi M., Damayanti S., Sudirman. (2014). Hubungan Kepatuhan Perawatan Kaki dengan Resiko Ulkus Kaki Diabetes Di Poliklinik DM RSU Andi Makkasauparepare. Jurnal IImiah Kesehatan Diagnosis, 4(1):10-18

Arifin, Zaenal. (2011). Penelitian Pendidikan: Metode dan Paradigma Baru. Bandung: PT Remaja Rosdakarya

Cavan, D. at al. (2015). Internasional Diabetes Federation Seventh Edition. dari www.diabetesatlas.org/

Desalu,O.O., Salawu, F.K, Jimoh,A.K.,
Adekoya, A.O., Busari, A.O., \& Olokaba, A.B. (2011). Diabetic foot Care: Self Reported Knowledge and Practice among Patients Attending Three Tertiary Hospital in Nigeria. Ghana Medical Journal, 45(2): 60-65

Diani, N. (2013). Pengetahuan dan Praktik Perawatan Kaki Pada Klien Diabetes Melitus Tipe 2 di Kalimantan Selatan. tersedia http://lontar.ui.ac.id/file?file=digital/20 334297-T32594-Noor\%20Diani.pdf

Ernawati. (2013). Penatalaksanaan Keperawatan Diabetes Melitus Terpadu. Jakarta: Mitra Wacana Media

Kowalak, J.P. (2012). Buku Ajar Patofisiologi. Jakarta: EGC

Maryunani, A. (2013). Step By Step Perawatan Luka Diabetes dengan Metode Perawatan Luka Modern. Jakarta: In Media

Notoatmodjo, S. (2012a). Metodologi Penelitian Kesehatan. Jakarta: Rineka Cipta

Notoatmodjo, S. (2012b). Promosi Kesehatan dan Perilaku Kesehatan. Jakarta: Rineka Cipta

Nursalam. (2013). Metodologi Penelitian IImu Keperawatan Edisi 3. Jakarta : Salemba Medika

Rias,Y,A. (2016). Hubungan Pengetahuan Dan Keyakinan Dengan Efikasi Diri Penyandang Diabetic Foot Ulcer. Jurnal Keperawatan Muhammadiyah. 1(1): 13-17.

Riwidikdo, H. (2013). Statistik Untuk Penelitian Kesehatan dengan Aplikasi Program dan SPSS. Yogyakarta: Pustaka Rihama

Sihombing, D. (2012). Gambaran Perawatan Kaki dan Sensasi Sensorik Kaki Pada asien Diabetes Melites Tipe 2 di Poliklinik DM RSUD. Universitas Padjajaran Bandung

Smeltzer, S.C., Bare, BG., Hinkle, J.L., \& Cheever, K.K (2010). Brunner \& Suddarth's: Textbook of Medical-Surgical Nursing $\left(12^{\text {th }} e d\right)$. Philadelphia: Lippincott Williams \& Wilkins.

Sofiana L.I, Elita V, Utomo W. (2012). Hubungan Antara Stress dengan Konsep Diri pada Penderita Diabetes Melitus Tipe 2. Jurnal Ners Indonesia. 2(2), 167-176.

Sundari A, Aulawi K, Harjanto D. (2009). Gambaran Tingkat Pengetahuan 
Srimiyati| Pengetahuan Pencegahan Kaki Diabetik Penderita Diabetes Melitus Berpengaruh Terhadap Perawatan Kaki

Tentang Ulkus Diabetik dan

Perawatan Kaki pada pasien

Diabetes Melitus Tipe 2. JIK, 4(3), 181-190.

Soegondo, Sidartawan. (2009).

Penatalaksanaan Diabetes Mellitus

Terpadu. Jakarta : FKUI

Word Health Organitation (2015). Fact Sheet

Diabetes. dari

http://www.who.int/mediacentre/ 